Pawee Magiera

Uniwersytet Papieski Jana Pawla II w Krakowie /

The Pontifical University of John Paul II in Krakow

iD https://orcid.org/0000-0002-6476-3635

\title{
W stulecie pierwszego sejmu Polski odrodzonej
}

(Rec.: Piotr Adam Tusiński, Sejm Ustawodawczy Rzeczypospolitej Polskiej 1919-1922, Wydawnictwo Sejmowe, Warszawa 2019, ss. 233).

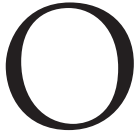

kragłe rocznice ważnych wydarzeń historycznych stanowia zwykle wdzięczna okazję do publikowania związanych bezpośrednio $z$ nimi okolicznościowych wydawnictw, skierowanych niejednokrotnie do szerszego grona odbiorców i nierzadko odznaczających się bogatą szatą graficzną. Nie inaczej było z przypadająca w 2019 r. setna rocznica otwarcia obrad Sejmu Ustawodawczego, pierwszego parlamentu II Rzeczypospolitej, powołanego do przygotowania konstytucji odrodzonego państwa polskiego. Rocznica ta stała się przyczynkiem do organizacji szeregu konferencji naukowych ${ }^{1}$ oraz do publikacji nowych prac $^{2}$ dotyczacych

${ }^{1}$ Warto w tym kontekście wymienić m.in. konferencję naukową Fundamenty Niepodległej. Sejm Ustawodawczy 1919-1922 zorganizowana w Warszawie 8 II 2019 r. w gmachu Sejmu i Senatu RP, a także konferencję W stulecie Sejmu Ustawodawczego RP 1919-2019, która odbyła się 9 X 2019 r. w gmachu Polskiej Akademii Umiejętności w Krakowie.

${ }^{2}$ Przykładowo można wspomnieć, że liczne artykuły dotyczące różnych zagadnień związanych bezpośrednio z Sejmem Ustawodawczym ukazały się w kolejnych numerach czasopisma naukowego „Przegląd Sejmowy” [dalej: PS] wydanych w 2018 i 2019 r. Por. zwłaszcza zawartość PS 2018, nr 6(149), który w całości poświęcono tematyce wspomnianego sejmu. Pojedyncze artykuły jego dotyczace znajduja się również w kilku kolejnych numerach czasopisma: PS 2019, nr 1(150); PS 2019, nr 2(151); PS 2019, nr 5(154). 
kształtu, funkcjonowania oraz dorobku wyłonionej w 1919 r. konstytuanty. Jedna $z$ takich publikacji, majacych na celu syntetyczne przedstawienie dziejów Sejmu Ustawodawczego w atrakcyjnej wizualnie i treściowo formie, jest nowa praca Piotra A. Tusińskiego, wydana w 2019 r. nakładem Wydawnictwa Sejmowego.

Autor omawianej publikacji wydaje się szczególnie predysponowany do podjęcia wskazanego tematu, jako że dał się on już wielokrotnie poznać jako znawca międzywojennego parlamentaryzmu, jego podstaw prawnych, zwyczajów i praktyki działania. W tym kontekście należy przywołać przede wszystkim jego cenna monografię z 2008 r. poświęcona wnikliwej analizie teoretycznych i praktycznych uwarunkowań postępowania ustawodawczego w polskim parlamencie w latach 1919-1939³. Zajmował się także różnymi kwestiami szczegółowymi dotyczaccymi ówczesnego parlamentaryzmu, jak np. problematyka sadów honorowych i marszałkowskich w izbach parlamentarnych okresu II Rzeczypospolitej ${ }^{4}$ oraz zasady ukonstytuowania się ich władz w poczatkach kolejnych kadencji ${ }^{5}$. Ponadto P.A. Tusiński jest autorem szeregu drobniejszych studiów dotyczących stricte funkcjonowania Sejmu Ustawodawczego ${ }^{6}$. W związku z tym całościowa monografia poświęcona konstytuancie wydaje się logicznym i konsekwentnym kierunkiem rozwoju dorobku naukowego Autora.

Warto zaznaczyć, że w literaturze przedmiotu brakowało dotąd monografii poświęconej wyłącznie Sejmowi Ustawodawczemu i przedstawiającej w kompleksowy sposób jego dzieje oraz dorobek. Powstało dotychczas bardzo wiele opracowań dostarczajacych wiedzy na ten temat, ale zazwyczaj były to albo publikacje szersze tematycznie, albo też studia nad zagadnieniami bardzo

${ }^{3}$ P.A. Tusiński, Postępowanie ustawodawcze $w$ Sejmie $i w$ Senacie II Rzeczypospolitej 1919-1939. Prawo - zwyczaje - praktyka parlamentarna, Radom 2008.

${ }^{4}$ Id e m, Sady honorowe i marszałkowskie $w$ Sejmie $i w$ Senacie II Rzeczypospolitej, PS 2001, nr 5(46), s. 45-69.

${ }^{5}$ I d e m, Norma prawna i obyczaj jako podstawa wyłaniania i funkcjonowania organów kierowniczych parlamentu II Rzeczypospolitej, „Prace Naukowe Politechniki Radomskiej im. Kazimierza Pułaskiego: Ekonomika” 1999, nr 1, s. 49-108.

${ }^{6}$ Należy zwrócić uwage zwłaszcza na ostatnio opublikowane prace: id e m, Procedury ustawodawcze w pierwszym sejmie odrodzonej Rzeczypospolitej Polskiej (1919-1922). Regulacja prawna i praktyka parlamentarna, PS 2018, nr 6(149), s. 159-193; idem, Pozaustawodawcze procedury parlamentarne $w$ pierwszym sejmie odrodzonej Rzeczypospolitej Polskiej (1919-1922). Regulacja prawna i praktyka parlamentarna, PS 2019, nr 2(151), s. 123-156. 
szczegółowymi. Przykładowo w pracach Andrzeja Ajnenkiela dotyczących parlamentu II Rzeczypospolitej można znaleźć osobne rozdziały poświęcone konstytuancie, podobnie jest w przypadku studium historii politycznej Polski z lat 1918-1933 autorstwa Adama Próchnika ${ }^{7}$. Ponadto wiele istotnych informacji jest rozsianych w obszerniejszych opracowaniach na tematy zwiazane $z$ konstytucjonalizmem oraz funkcjonowaniem naczelnych organów państwa w omawianym okresie ${ }^{8}$. Osobno i dobrze omówione są również kwestie związane $z$ wyborami do Sejmu Ustawodawczego, głównie za sprawą prac Kamila Kacperskiego9. Wyłącznie zagadnieniu parlamentu polskiego $z$ lat 1919-1922 poświęcono do tej pory tylko krótkie artykuły naukowe ${ }^{10}$. W związku z powyższym próbę dokonania całościowej prezentacji tematu w obrębie jednej monografii, podjęta przez P.A. Tusińskiego, należy ocenić jako ważną i potrzebną inicjatywę.

Przechodząc do szczegółowego omówienia recenzowanej publikacji, należy podkreślić, że nie jest ona wcale praca całkowicie nowa i samoistna. Stanowi bowiem - jak to zreszta zaznaczono na ostatniej stronie samej monografii - jedynie zmodyfikowana oraz znaczaco rozbudowaną wersję artykułu Autora, który ukazał się drukiem w 2008 r. w czasopiśmie naukowym „Niepodległość i Pamięć", wydawanym przez Muzeum Niepodległości w Warsza$w_{i e}{ }^{11}$. Jednocześnie $\mathrm{w}$ przeciwieństwie do tego artykułu omawianą monografię pozbawiono znajdującego się w nim oryginalnie aparatu naukowego w postaci przypisów.

7 A. Ajnenkiel, Parlamentaryzm II Rzeczypospolitej, Warszawa 1975; id em, Historia sejmu polskiego, t. II, cz. 2 (II Rzeczpospolita), Warszawa 1989; A. Pró chnik, Pierwsze piętnastolecie Polski niepodległej, Warszawa 1983.

8 Por. m.in. S. Krukowski, Geneza konstytucji z 17 marca 1921 r., Warszawa 1977; M. Pietrzak, Rzady parlamentarne w Polsce w latach 1919-1926, Warszawa 1969; Sejmy Drugiej Rzeczypospolitej, red. A. Zakrzewski, Warszawa 1990.

${ }^{9}$ Por. m.in. K. Kac perski, System wyborczy do Sejmu i Senatu u progu Drugiej Rzeczypospolitej, Warszawa 2007; id e m, Prawo wyborcze do Sejmu Ustawodawczego, PS 2018, nr 6(149), s. 57-84.

10 S. Krukowski, Sejm Ustawodawczy 1919-1922. Uwagi o składzie i dziaŁalności, „Czasopismo Prawno-Historyczne” 1986, t. XXXVIII, z. 1, s. 93-109; D. Malec, Sejm Ustawodawczy 1919-1922. W 90. rocznice pierwszego posiedzenia, PS 2009, nr 1(90), s. 9-29.

11 P.A. Tu sińs ki, „Sejm Polski domu swego ojczystego jedynym panem i gospodarzem” (odrodzenie Sejmu Rzeczypospolitej w 1919 r.), „Niepodległość i Pamięć” 2008, nr 28, s. 127-153. 
Powstała na bazie artykułu książka autorstwa P.A. Tusińskiego ma bardzo czytelna strukturę, umożliwiająca odbiorcy łatwą orientację w przekazywanej treści. Publikacja składa się z 11 krótkich rozdziałów podzielonych wedle kryterium rzeczowego, choć z zachowaniem podstawowej chronologii (zwłaszcza w odniesieniu do początkowych części). W obrębie każdego $z$ nich ważnym uzupełnieniem tekstu jest zamieszczony bezpośrednio po nim bogaty materiał ikonograficzny, który stanowia liczne, dobrze dobrane i wykonane w wysokiej jakości reprodukcje zdjęć oraz dokumentów odnoszących się do różnych aspektów działania Sejmu Ustawodawczego i korespondujących ściśle $z$ tematyka danego rozdziału. Pracę podzielono na następujące rozdziały: Idea Sejmu przed odzyskaniem niepodległości (s. 5-22), Prace przygotowawcze do zwołania Sejmu Ustawodawczego - ordynacja wyborcza i proces wyłaniania składu izby (s. 23-50), Inauguracja obrad Sejmu Ustawodawczego (s. 51-66), Gmach Sejmu oraz organizacja pracy Izby (s. 67-88), Pozycja ustrojowa Sejmu Ustawodawczego oraz status prawny posłów (s. 89-116), Kształt polityczny i struktura klubowa Sejmu Ustawodawczego (s. 117-134), Ustrój wewnętrzny Sejmu Ustawodawczego (s. 135-150), Procedury sejmowe (s. 151-170), Relacje $z$ egzekutywa (s. 171-188), Charakterystyka składu osobowego Sejmu Ustawodawczego (s. 189-210), Dorobek Sejmu Ustawodawczego i ocena Konstytuanty (s. 211-228). Zastosowany podział nie budzi większych watpliwości, jest klarowny oraz ujmuje całościowo i wszechstronnie problematykę związana z Sejmem Ustawodawczym. Książkę wieńczy spis wykorzystanych źródeł i literatury, podzielony czytelnie na odpowiednie kategorie (s. 229-233).

Warto zaznaczyć, że całość została wydana $z$ dużą dbałością o szczegóły, o czym może świadczyć umieszczenie książki w twardej oprawie oraz wydruk na kredowym papierze. Na wysoka wartość estetyczna publikacji wpływa też utrzymanie tła okładki oraz detali wewnątrz książki (numery stron, obramowania fotografii, strony tytułowe rozdziałów itd.) w tej samej, efektownej barwie delikatnie lśniącej miedzi. Staranność szaty graficznej, likwidacja przypisów, jak również wzmiankowana już duża liczba zamieszczonych materiałów ikonograficznych w stosunku do objętości samego tekstu (tylko około 60 stron zawierających tekst wobec 233 ogółem, aż 150 ilustracji) wskazuja niewatpliwie na rys popularnonaukowy omawianej pracy. Można założyć, że intencją wydawcy i Autora było dotarcie do jak najszerszego grona odbiorców oraz zainteresowanie 
ich tematyka Sejmu Ustawodawczego z okazji setnej rocznicy jego otwarcia. W związku $z$ tym nadano tej publikacji kształt dość ekskluzywnie wydanego albumu, zawierającego atrakcyjnie podane, a przy tym rzetelne kompendium wiedzy o konstytuancie.

Mimo powyższych uwag należy jednak zaznaczyć, że omawiana książka, obok atrakcyjnej formy wydania, ma też istotna wartość merytoryczna, a jej treść odpowiada aktualnemu stanowi wiedzy naukowej na podjęty temat. Spora w tym niewatpliwie zasługa Autora, który nieraz już udowodnił, że dysponuje warsztatem uprawniającym go do syntetycznego i uporzadkowanego przedstawienia tych zagadnień. Treść kolejnych rozdziałów nie budzi większych zastrzeżeń z punktu widzenia ich merytorycznej zawartości. Sa one w przeważającej mierze wiernie oparte na poszczególnych częściach wzmiankowanego już artykułu, stanowiącego pierwowzór omawianej publikacji. Na szczególna uwage zasługują środkowe rozdziały poświęcone organizacji pracy konstytuanty, jej pozycji ustrojowej, procedurom parlamentarnym oraz relacjom $z$ innymi organami państwa. Są one bowiem w większym stopniu oryginalne i wnoszą ciekawe spostrzeżenia, korespondujące ściśle $z$ głównymi zainteresowaniami badawczymi Autora.

Wattpliwości nie budzi również zasadniczy dobór wykorzystanej literatury i źródeł, które wymieniono na końcu książki. Wykaz ten zawiera właściwie wszystkie najważniejsze pozycje odnoszące się do podjętej tematyki. Można jednak wskazać na drobne braki w przypadku opracowań podejmujących zagadnienia szczegółowe. Przykładowo Autor uwzględnił pracę Szymona Rudnickiego o Żydach w parlamencie II Rzeczypospolitej ${ }^{12}$, a jednocześnie nie wymienił monografii Janusza Fałowskiego poświęconej konkretnie posłom żydowskim w Sejmie Ustawodawczym ${ }^{13}$. Ponadto nie przywołał w spisie literatury dwóch ważnych publikacji na temat drugiej mniejszości narodowej mającej reprezentantów w konstytuancie, czyli Niemców ${ }^{14}$. W przypadku wymienionych źródeł należy docenić wykorzystanie parlamentariów - druków i sprawozdań stenograficznych $z$ posiedzeń izby, stanowiących niezbędny

\footnotetext{
12 S. Rudnicki, Żydzi w parlamencie II Rzeczypospolitej, Warszawa 2004.

13 J. Fałowski, Posłowie żydowscy w Sejmie Ustawodawczym 1919-1922, Częstochowa 2000.

${ }^{14}$ I d e m, Parlamentarzyści mniejszości niemieckiej w Drugiej Rzeczypospolitej, Częstochowa 2000; P. Hau s er, Przedstawiciele mniejszości niemieckiej w parlamencie II Rzeczypospolitej, Warszawa 2014.
} 
i podstawowy materiał do badań nad parlamentaryzmem. Autor sięgną również szeroko do zachowanych w maszynopisach oraz opublikowanych pamiętników i źródeł wspomnieniowych, pozostawionych przez uczestników i obserwatorów ówczesnej sceny politycznej. Wydaje się jednak, że warto było w tym kontekście uzupełnić listę choćby o wspomnienia posła endecji Stanisława Głąbińskiego ${ }^{15}$ czy reprezentującego wówczas w konstytuancie Narodową Partię Robotniczą Stanisława Wachowiaka ${ }^{16}$. Nie wymieniono $\mathrm{w}$ spisie także wielokrotnie wznawianych wspomnień Wincentego Witosa ${ }^{17}$, choć Autor powołał się na nie kilkakrotnie w samym tekście, co świadczy jedynie o drobnym przeoczeniu przy zestawianiu bibliografii. Uwage zwraca również niedostateczna - jak się wydaje - kwerenda prasowa, ograniczona wyłącznie do „Kuriera Polskiego”, podczas gdy wielu informacji o działalności Sejmu Ustawodawczego dostarczał przecież szereg ówczesnych gazet, zarówno o zasięgu ogólnopolskim (np. „Ilustrowany Kurier Codzienny”), jak i lokalnym (choćby krakowski „Czas”, „Gazeta Warszawska”, „Kurier Poznański”), w tym występujące licznie w okresie międzywojennym oficjalne organy prasowe poszczególnych ugrupowań politycznych (przykładowo „Robotnik”, „Wyzwolenie”, „Piast”, „Rzeczpospolita”, „Lud Katolicki”).

Omawiana praca została wydana $z$ widoczna starannością, dlatego też nie zawiera ona zbyt wielu poważnych błędów. Należy jednak zwrócić uwagę na kilka drobnych, szczegółowych usterek. Dotyczą one głównie rozdziału poświęconego strukturze klubowej Sejmu Ustawodawczego. Kilkakrotnie Autor pisze o „Polskim Związku Ludowym” i „Narodowym Związku Ludowym” (s. 120-121), mimo że poprawne formy nazw obu formacji politycznych, a zarazem klubów poselskich brzmią: „Polskie Zjednoczenie Ludowe” i „Narodowe Zjednoczenie Ludowe” ${ }^{18}$. Wydaje się, że jest to jednak tylko zwykła omyłka pisarska, gdyż w tekście występują wymiennie obie wspomniane formy. Podobny charakter ma użycie nieadekwatnej nazwy „Klubu Lewicy Chłopskiej” (s. 122) wobec Klubu

15 S. Głąbiński, Wspomnienia polityczne, Pelplin 1939.

16 S. W achowiak, Czasy, które przeżyłem. Wspomnienia z lat 1890-1939, Warszawa 1983.

17 Por. choćby W. Witos, Moje wspomnienia, cz. 1-2, oprac. E. Karczewski, J.R. Szaflik, Warszawa 1988-1990.

18 Por. A. Ajnenkiel, Historia sejmu..., s. 21, 25-26; T. Rze pecki, Sejm Rzeczypospolitej Polskiej 1919 roku, Poznań 1920, s. 286-287. 
Lewicy Ludowej, utworzonego u schyłku prac konstytuanty przez Józefa Putka ${ }^{19}$. Ponadto trudno zgodzić się $z$ twierdzeniem Autora, że Komunistyczna Frakcja Poselska powstała „w ostatnich miesiacach działalności Sejmu Ustawodawczego" (s. 122), skoro za moment jej pojawienia się w sejmie powszechnie uznaje się lipiec $1921 \mathrm{r}^{20}$ Niedopatrzenia tego rodzaju sa jednak stosunkowo nieliczne i nie wpływają w żaden sposób na odbiór merytoryczny książki.

Za istotną wadę recenzowanej publikacji należy uznać wspomniany już brak przypisów. Ich likwidacja wynika zapewne $z$ celowego dążenia do nadania książce charakteru popularnonaukowego i niezrażania potencjalnego odbiorcy rozbudowanym aparatem naukowym. Niemniej wydaje się, że możliwe było choćby umieszczenie przypisów w odrębnej sekcji na końcu książki. Podniosłoby to niewatpliwie walor naukowy opracowania oraz pozwoliłoby na łatwe śledzenie źródła przedstawianych informacji, zwłaszcza zaś licznie wykorzystywanych $\mathrm{w}$ tekście cytatów. Usunięcie przypisów jest tym bardziej niezrozumiałe, że w artykule stanowiacym pierwowzór książki zawierały one wiele ciekawych i wartościowych spostrzeżeń. Za wadę uznać należy także nienumerowanie ilustracji oraz nieumieszczenie ich pełnego spisu na końcu publikacji. Oba zaniechania utrudniają bowiem znaczacco poruszanie się po bogatym materiale ikonograficznym, stanowiącym większość objętości książki. Brakuje w omawianej pracy także krótkiego, odrębnego rozdziału poświęconego głównemu zadaniu Sejmu Ustawodawczego, jakim były prace nad konstytucją i ich efekt w postaci Konstytucji marcowej z $1921 \mathrm{r}$. Zagadnienie to doczekało się już oczywiście bardzo bogatej i wyczerpujaccej literatury przedmiotu, nie ma więc sensu podejmować go na nowo. Mimo to umieszczenie krótkiej syntezy stanu badań w tym aspekcie byłoby pożądane i niewątpliwie dopełniłoby treściowo recenzowana pracę, która - jak się wydaje ma przecież ambicję całościowego i wieloaspektowego przedstawienia dziejów Sejmu Ustawodawczego.

Podsumowując, należy stwierdzić, że recenzowana praca, mimo wskazanych drobnych niedociągnięć, jest klarownie skonstruowana, merytorycznie poprawna, a nade wszystko bardzo starannie i atrakcyjnie wydana publikacja, która jasno syntetyzuje

19 M. Witkowski, Trybun ludowy. Rzecz o Józefie Putku, „Wadoviana. Przegląd Historyczno-Kulturalny" 2012, t. XV, s. 85.

${ }^{20}$ A. Ajnenkie1, Historia sejmu..., s. 24, 26. 
i porządkuje dotychczasowy stan wiedzy na temat Sejmu Ustawodawczego $z$ lat 1919-1922. Jest ona jednocześnie pierwsza monografią w całości poświęcona temu parlamentowi. Książka P.A. Tusińskiego ma jednak głównie charakter popularnonaukowy, a jej forma zbliżona jest do wydawnictwa albumowego. Stanowi zatem przede wszystkim ciekawą dla szerszego odbiorcy publikację rocznicowa, mająca popularyzować wiedzę o pierwszym sejmie Polski odrodzonej $z$ okazji stulecia jego otwarcia. Co istotne, recenzowana praca nie jest pozycją zupełnie nowa - opiera się na tekście publikowanego wcześniej artykułu naukowego Autora. W zwiąku $z$ tym, mimo istotnych i niewatpliwych walorów popularyzatorskich omawianej książki, niech wolno będzie piszącemu te słowa wyrazić pewne rozczarowanie, że P.A. Tusiński nie zdecydował się na jej kartach na całkowicie nowe i opatrzone pełnym aparatem naukowym, a zarazem znacznie obszerniejsze omówienie tytułowego tematu. Zagadnienie Sejmu Ustawodawczego nadal bowiem nie zostało wyczerpane badawczo i może być obiektem różnorodnych, pogłębionych studiów, czemu sprzyja zwłaszcza ułatwiony obecnie przez digitalizację dostęp do źródeł parlamentarnych i prasowych $z$ epoki. Autor recenzowanej publikacji niewatpliwie jest znakomitym znawcą tej problematyki i należy żywić nadzieję, że nie jest to jego ostatnia praca $z$ tego zakresu, a analizowana ksiązka - jako potrzebna i pożyteczna poznawczo wykładnia dziejów konstytuanty - uzyska może w przyszłości bardziej rozbudowana i w pełni naukowa formę.

\section{Bibliografia}

\section{Ź RÓDEA DRUKOWANE}

Głąbiński S., Wspomnienia polityczne, Pelplin 1939.

Wachowiak S., Czasy, które przeżyłem. Wspomnienia z lat 1890-1939, Warszawa 1983.

Witos W., Moje wspomnienia, cz. 1-2, oprac. E. Karczewski, J.R. Szaflik, Warszawa 1988-1990.

\section{Opracowania}

Ajnenkiel A., Historia sejmu polskiego, t. II, cz. 2 (II Rzeczpospolita), Warszawa 1989.

Ajnenkiel A., Parlamentaryzm II Rzeczypospolitej, Warszawa 1975. 
Fałowski J., Parlamentarzyści mniejszości niemieckiej w Drugiej Rzeczypospolitej, Częstochowa 2000.

Fałowski J., Posłowie żydowscy w Sejmie Ustawodawczym 1919-1922, Częstochowa 2000.

Hauser P., Przedstawiciele mniejszości niemieckiej w parlamencie II Rzeczypospolitej, Warszawa 2014.

Kacperski K., Prawo wyborcze do Sejmu Ustawodawczego, „Przegląd Sejmowy” 2018, nr 6(149), s. 57-84.

Kacperski K., System wyborczy do Sejmu i Senatu u progu Drugiej Rzeczypospolitej, Warszawa 2007.

Krukowski S., Geneza konstytucji z 17 marca 1921 r., Warszawa 1977.

Krukowski S., Sejm Ustawodawczy 1919-1922. Uwagi o składzie i działalności, „Czasopismo Prawno-Historyczne” 1986, t. XXXVIII, z. 1, s. 93-109.

Malec D., Sejm Ustawodawczy 1919-1922. W 90. rocznice pierwszego posiedzenia, „Przegląd Sejmowy” 2009, nr 1(90), s. 9-29.

Pietrzak M., Rzady parlamentarne w Polsce w latach 1919-1926, Warszawa 1969.

Próchnik A., Pierwsze piętnastolecie Polski niepodległej, Warszawa 1983.

Rudnicki S., Żydzi w parlamencie II Rzeczypospolitej, Warszawa 2004.

Rzepecki T., Sejm Rzeczypospolitej Polskiej 1919 roku, Poznań 1920.

Sejmy Drugiej Rzeczypospolitej, red. A. Zakrzewski, Warszawa 1990.

Tusiński P.A., Norma prawna i obyczaj jako podstawa wyłaniania i funkcjonowania organów kierowniczych parlamentu II Rzeczypospolitej, „Prace Naukowe Politechniki Radomskiej im. Kazimierza Pułaskiego: Ekonomika” 1999, nr 1, s. 49-108.

Tusiński P.A., Postępowanie ustawodawcze $w$ Sejmie $i w$ Senacie II Rzeczypospolitej 1919-1939. Prawo - zwyczaje - praktyka parlamentarna, Radom 2008.

Tusiński P.A., Pozaustawodawcze procedury parlamentarne $w$ pierwszym sejmie odrodzonej Rzeczypospolitej Polskiej (1919-1922). Regulacja prawna i praktyka parlamentarna, „Przegląd Sejmowy” 2019, nr 2(151), s. 123-156.

Tusiński P.A., Procedury ustawodawcze $w$ pierwszym sejmie odrodzonej Rzeczypospolitej Polskiej (1919-1922). Regulacja prawna i praktyka parlamentarna, „Przegląd Sejmowy” 2018, nr 6(149), s. 159-193.

Tusiński P.A., Sądy honorowe i marszałkowskie $w$ Sejmie $i$ w Senacie II Rzeczypospolitej, „Przegląd Sejmowy” 2001, nr 5(46), s. 45-69.

Tusiński P.A., „Sejm Polski domu swego ojczystego jedynym panem i gospodarzem” (odrodzenie Sejmu Rzeczypospolitej w 1919 r.), „Niepodległość i Pamięć” 2008, nr 28, s. 127-153.

Tusiński P.A., Sejm Ustawodawczy Rzeczypospolitej Polskiej 1919-1922, Warszawa 2019.

Witkowski M., Trybun ludowy. Rzecz o Józefie Putku, „Wadoviana. Przegląd Historyczno-Kulturalny" 2012, t. XV, s. 75-112. 
NotKa O AUTORZE:

Mgr Pawel Magiera - absolwent studiów prawniczych (2015) i historycznych (2017) w Uniwersytecie Jagiellońskim w Krakowie. Od 2017 r. doktorant historii na Wydziale Historii i Dziedzictwa Kulturowego Uniwersytetu Papieskiego Jana Pawła II w Krakowie. Autor kilkunastu artykułów publikowanych w czasopismach naukowych i monografiach zbiorowych, współautor monografii poświęconej praktyce orzeczniczej wojskowych sądów rejonowych w Katowicach i w Krakowie (2020).

Zainteresowania naukowe: historia polityczna i ustrojowa Polski w XX w., w szczególności dzieje parlamentaryzmu polskiego w okresie Drugiej Rzeczypospolitej.

$\nabla$ paulus.magiera@gmail.com 